\title{
Rustification as a collateral process in clay-illuvial soils of northern Poland
}

\author{
Marcin Świtoniak* \\ Nicolaus Copernicus University in Toruń, Faculty of Earth Sciences and Spatial Management, ul. Gagarina 11, 87-100 Toruń, Poland \\ * Dr hab. M. Świtoniak, swit@umk.pl, ORCID iD: https://orcid.org/0000-0002-9907-7088
}

Received: 20.06.2021

Accepted: 28.10.2021

Associated editor: V. Penížek

\section{Keywords}

Zonal soils

Siderik horizon

Luvisols

Brunic Arenosols

Lessivage

\begin{abstract}
The lessivage (clay-illuviation) and rustification are among the two most common soil-forming processes in soil cover of Poland. The horizons of illuvial accumulation of the clay fraction are observed in approx. 50\% of Polish soils, while rusty soils constitute about $14 \%$ - that is almost half of all sandy soils in the country. Due to the different conditions of both processes - mainly lithological in nature - they are generally perceived as separable phenomena leading to the formation of two different types of soils - clay-illuvial soils (WRB - Luvisols) and rusty soils (Brunic Arenosols). However, in some soil profiles, especially those formed in sands covering glacial tills, the effects of both of these soil-forming processes are observed. The aim of the study was to characterize the soils with the features related to the illuviation (lessivage) of the clay fraction and the accumulation of iron sesquioxides in the form of iron coatings formed in-situ in the sandy material (rustification). In order to check how often these processes take place simultaneously, 29 soil profiles with a texture enabling the simultaneous acting of both processes in the young glacial areas of northern Poland were analyzed. In as many as $66 \%$ of cases, the presence of features related to both processes were found. The lack of the rustification was recorded predominantly in arable soils - often shallowed by erosion or with a clear stagnation of water in the eluvial horizons. Most of the studied soils were classified as texturally contrasted rusty clay-illuvial soils (WRB - Abruptic Luvisols (Brunic)) or lamellic rusty clay-illuvial soils (WRB - Lamellic Luvisols (Brunic)). Thus, both processes in soils developed from cover sands underlying by glacial tills are complementary to each other, and the profiles of A-Bv-Et-2Bt-2Ck morphology (designation of horizons according to Polish Soil Classification (PSC, 2019)) should be perceived as fully formed and undisturbed by human activity.
\end{abstract}

\section{Introduction}

Soil cover of Poland was formed under the influence of humid climate with a total precipitation higher than evaporability, determining leaching water regime in zonal soils. The climatically conditioned, zonal soils: clay-illuvial, podzol, brown and rusty soils, constitute $75 \%$ of the entire area of the country (Bednarek and Prusinkiewicz, 1997). Due to the above, common soil-forming processes include decalcification and acidification of the upper soil horizons and translocations of individual mineral components down the soil profile. It is therefore not surprising that there is a widespread presence of clay-illuvial soils (Luvisols or Retisols according to WRB) developed from glacial tills or of silt and loess deposits (about 50\% of all soils - Sykuła et al., 2019) and podzolic soils (Podzols) evolved from sandy materials (about $12 \%$ of Poland). Both of these two units have morphology generally described as A-E-B-C with well-developed eluvial and illuvial horizons - pedogenic features common in subboreal humid climate. In some cases, these soils may not have eluvial horizons, due to lateral podzolization (Jankowski, 2014a) or agrotechnical treatments and slope processes often caused by human activities (Sinkiewicz, 1998; Kobierski, 2013; Podlasiński, 2013; Świtoniak et al., 2016). The other two types of zonal units - brown and rusty soils - include pedons with B horizons developed directly below humus A horizons. In the case of brown soils (Cambisols), which occur mainly on the slopes in the foothill regions of southern Poland, the A-B-C morphology may result from the lateral runoff of soil solutions or formation of slope covers (Kacprzak and Derkowski, 2007; Waroszewski et al., 2016; Kowalska et al. 2021. The most "inadequate" in the context of humid climate seems to be rusty soils (WRB - Brunic Arenosols) - sandy and highly permeable soils common in the Polish lowlands - covering about $14 \%$ of whole country. These soils, like mentioned above clay-illuvial pedons, were developed under deciduous forests in a humid climate (Jankowski et al. 2011). The diagnostic horizons of these soils, Bv - siderik, (names and designation of horizons are according to Polish Soil Classification - PSC 2019) have an orangebrown color due to the in-situ weathering accumulation of iron 
and aluminium compounds in coarse materials - sands, weak loamy sands or loamy sands, containing from 0 to $15 \%$ of the clay fraction. This process in Polish literature is called rustification (Konecka-Betley, 1968) as opposed to the process of brunification (e.g. Duchaufour, 1982; Schaetzl and Anderson, 2005) which taking place in finer-grained materials (mainly loams or silts) leading to the formation of kambik (WRB - cambic) horizons. Therefore, siderik horizons are close to the kambik except texture. Although the genesis of rusty soils has been the subject of research by many authors (e.g. Konecka-Betley, 1968; Kowalkowski et al., 1981, Prusinkiewicz and Bednarek, 1983; Bednarek, 1991; Konecka-Betley and Janowska, 1996; Kruczkowska et al., 2020), still some issues remain unclear. Their A-B-C morphology does not reflect leaching water regime. Because most of rusty soils occur in flat forest areas protected against erosion, lack of eluvial horizons cannot be explained by lateral movement of percolate or influence of slope processes. How is it possible that rusty soils, highly permeable for rain water, with in-situ accumulation of aluminum and iron sesquioxides in siderik Bv horizon are formed, next to clay-illuvial soils with thick and clearly marked eluvial horizons developed in the same climatic conditions and under similar vegetation? Some arguments in this discussion can provide the study of soils developed from sediments that allow simultaneous (or successive) development of both processes - rustification and clay-illuviation. Sandy mantles covering glacial tills or sands containing amounts of clay fraction high enough to develop argik (argic in WRB) horizons (loamy sands or sands with "inserts" of finer material) are best suited for this purpose. Some authors already describe soils with sandy deposits covering loamy materials where brunification or rustification and clay-illuviation processes overlap in one profile (eg. Kühn 2003; Kuhn et al. 2006; Yost et al. 2019).

The aim of this study is to determine how often and in what environmental conditions effects of clay-illuviation and rustification occur at the same time in the soil profiles in north part of
Poland. An additional task was also to appraise the usefulness of the latest version of the Polish Soil Classification (2019) and WRB (IUSS Working Group WRB, 2015) in expressing the features of both processes in the name of soil taxon.

\section{Study area and methods}

The study was carried out in young morainic areas of North Poland within four mesoregions (Kondracki, 2009; Solon et al., 2018): Brodnica Lake District, Chełmno Lake District, Drwęca Valley, Świecie Plateau. The area is located in the zone of moist and cool temperate climate (IPCC, 2006). According to Köppen-Geiger Climate Classification, the region is located in the fully humid zone with temperate and warm summer (Kottek et al., 2006). Average annual air temperature (based on data from period 1951-1970) in the central part of studied area is $7.5^{\circ} \mathrm{C}$ (Wójcik and Marciniak, 1987a). The warmest month is July with average air temperature of $17.5^{\circ} \mathrm{C}$, and the coldest month is February with average air temperature of $-3.3^{\circ} \mathrm{C}$. The average annual precipitation is $519 \mathrm{~mm}$ with the majority of precipitation occurring in summer and the maximum in July - $101 \mathrm{~mm}$ (Wójcik and Marciniak, 1987b). The humid period lasts for a whole year conditioning the leaching soil-water regime in pedons with good natural drainage.

The study area is located within the range of Pomeranian phase (16-17 kyr BP) of the Weichselian glaciation (Niewiarowski, 1959, 1986; Niewiarowski and Wysota, 1986; Marks, 2012), which left deposits of morainic glacial tills or fluvioglacial sands and gravels in the analyzed area.

In total 29 soil profiles were investigated. Almost all soils were located in moraine undulating and hilly plateaus. One profile was on the border between the plateau and slope of a marginal ice valley. In 27 cases texturally contrasted deposits occured - fluvioglacial or ablation cover sands (sands, weak loamy
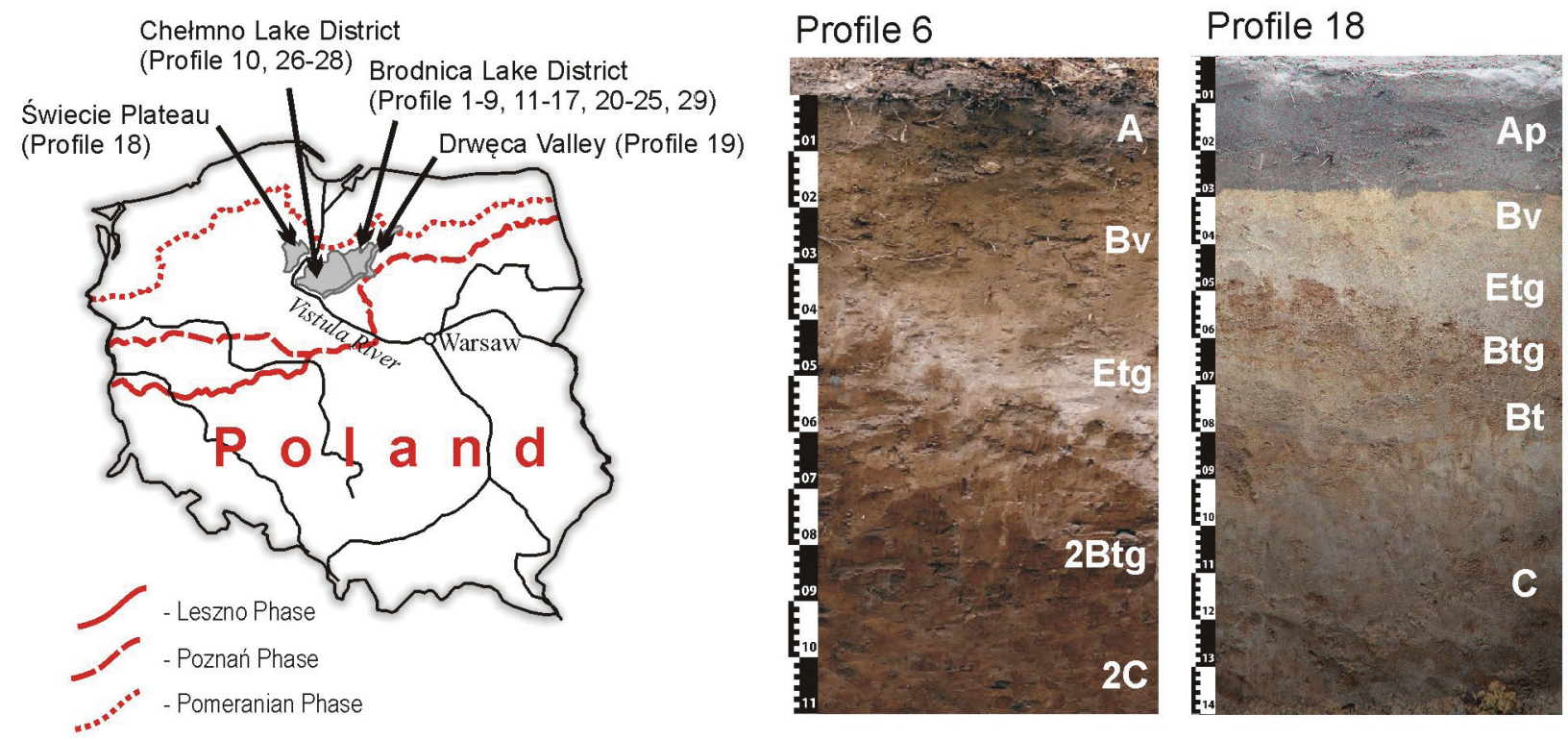

Fig. 1. Study area and examples of investigated pedons with clay illuviation and rustification: profile 6 - soil developed from sand cover on glacial till, profile 18 - soil developed from deep sands with inclusions and lamellaes of loamy sands 
sands and loamy sand in texture) overlies glacial tills (mainly loamy texture - Table 1). Lithogenic discontinuities separating sandy deposits from glacial tills were at the ca. $70 \mathrm{~cm}$ depth. Two profiles were developed in deep (more than $2 \mathrm{~m}$ ) sands contain lamination or inclusions of finer-grained material. Twenty soils were covered by managed forests - with canopy layer dominated by pines (Pinus sylvestris) and species typical for hornbeam forest (Carpinus betulus, Tilia cordata, Quercus $s p$ ) predominates in understory, herb layer and forest floor. Nine soil pits were located in agricultural areas - arable fields.

Disturbed soil samples were taken from every genetic soil horizons. Standard soil analyses were performed using the methods as follows: total organic carbon (TOC) content - by Tiurin's method; total nitrogen content by Kjeldahl method;

Table 1

Selected properties of the studied soils

\begin{tabular}{|c|c|c|c|c|c|c|c|c|c|c|}
\hline \multirow[t]{2}{*}{ No } & \multirow[t]{2}{*}{ use } & \multirow{2}{*}{$\begin{array}{l}\text { Lithic } \\
\text { discontinuity } \\
\text { depth [cm] }\end{array}$} & \multicolumn{2}{|c|}{ Texture } & \multicolumn{2}{|c|}{ A horizon } & \multicolumn{2}{|l|}{$\mathrm{Bv}$} & \multirow{2}{*}{$\begin{array}{l}\text { pH under } \\
\text { A horizon }\end{array}$} & \multirow[t]{2}{*}{ Horizon sequence } \\
\hline & & & $\begin{array}{l}\text { Above } \\
\text { lithic } \\
\text { disc. }\end{array}$ & $\begin{array}{l}\text { Below lithic } \\
\text { discontinuity }\end{array}$ & Corg [\%] & $\begin{array}{l}\text { Thickness } \\
\text { [cm] }\end{array}$ & $\begin{array}{l}\text { Thickness } \\
\text { [cm] }\end{array}$ & $\begin{array}{l}\text { Lower } \\
\text { boundary } \\
\text { depth [cm] }\end{array}$ & & \\
\hline 1 & $\mathrm{~F}$ & 60 & LS & SCL & 1.42 & 10 & 35 & 45 & 4.8 & O-A-Bv-Etg-2Bt-2Ck \\
\hline 2 & $\mathrm{~F}$ & 45 & LS & $\mathrm{L}$ & 1.63 & 10 & 15 & 25 & 4.8 & O-A-Bv-Et-2Bt-2Ck \\
\hline 3 & $\mathrm{~F}$ & 55 & LS & SL & 1.47 & 15 & 10 & 25 & 4.7 & O-A-Bv-Et-2Bt-2Ck \\
\hline 4 & $\mathrm{~F}$ & 75 & LS & $\mathrm{L}$ & 1.44 & 12 & 43 & 55 & 4.9 & O-A-Bv-Et-2Bt-2C \\
\hline 5 & $\mathrm{~F}$ & 58 & LS & SL & 2.55 & 15 & 33 & 48 & 4.7 & O-A-Bv-Etg-2Btg-2Cg \\
\hline 6 & $\mathrm{~F}$ & 52 & LS & $\mathrm{L}$ & 1.25 & 10 & 32 & 42 & 5.2 & O-A-Bv-Etg-2Btg-2C \\
\hline 7 & $\mathrm{~F}$ & 40 & LS & SCL & 2.44 & 12 & 8 & 20 & 4.6 & O-A-Bv-Et-2Bt-2Ck \\
\hline 8 & $\mathrm{~F}$ & 82 & LS & SL & 3.03 & 9 & 39 & 45 & 4.6 & O-A-Bv-Et-2Bt-2C \\
\hline 9 & $\mathrm{~F}$ & 35 & LS & SCL & 1.38 & 10 & 10 & 20 & 5.6 & O-A-Bv-Et-2Bt-2Ck \\
\hline 10 & $\mathrm{~A}$ & 102 & LS & $\mathrm{L}$ & 0.90 & 35 & 35 & 70 & 5.9 & Ap-Bv-Et-2Bt \\
\hline 11 & A & 80 & LS & SL & 0.49 & 35 & 20 & 55 & 6 & Ap-Bv-Et-2Bt-2Ck \\
\hline 12 & $\mathrm{~F}$ & 95 & S & LS & 1.48 & 20 & 25 & 45 & 5.2 & O-A-Bv-Et-2Bt (lamellae) \\
\hline 13 & $\mathrm{~F}$ & 100 & LS & SL & 0.69 & 20 & 35 & 55 & 4.8 & O-A-Bv-Et-2Bt \\
\hline 14 & $\mathrm{~F}$ & 74 & LS & SCL & 2.88 & 15 & 59 & 74 & 5.3 & $\mathrm{O}-\mathrm{A}-\mathrm{Bv}-2 \mathrm{Bt}$ \\
\hline 15 & $\mathrm{~F}$ & 77 & LS & SL & 1.44 & 10 & 45 & 55 & 4.9 & O-A-Bv-Et-2Bt (lamellae) \\
\hline 16 & $\mathrm{~F}$ & 110 & LS & SL & 1.77 & 12 & 58 & 70 & 4.7 & O-A-Bv-Etg-2Bt (lamellae) \\
\hline 17 & $\mathrm{~F}$ & 90 & LS & SL & 2.14 & 15 & 45 & 60 & 5 & O-A-Bv-Etg-2Bt (lamellae) \\
\hline 18 & A & $50^{*}$ & S & LS & 0.66 & 30 & 10 & 40 & 5.1 & Ap-Bv-Et-Btg (lamellae)-Bt-C \\
\hline 19 & $\mathrm{~F}$ & $70^{*}$ & S & SL & 1.26 & 20 & 50 & 70 & 5.7 & O-A-Bv-C with lamellae \\
\hline 20 & $\mathrm{~F}$ & 70 & LS & SL & 2.37 & 25 & 20 & 45 & 4.8 & O-A-Bv-Cgg-2Cgg \\
\hline 21 & $\mathrm{~F}$ & 100 & LS & SL & 1.41 & 10 & 15 & 25 & 4.7 & O-A-Bv-C-2Cg \\
\hline 22 & $\mathrm{~F}$ & 100 & LS & SL & 1.87 & 12 & 43 & 55 & 4.6 & O-A-Bv-C-2Cgg \\
\hline 23 & $\mathrm{~A}$ & 45 & LS & $\mathrm{L}$ & 0.61 & 25 & - & - & 6.7 & Ap-Etg-2Btg-2Ckg \\
\hline 24 & $\mathrm{~A}$ & 65 & LS & $\mathrm{L}$ & 0.72 & 30 & - & - & 6.8 & Ap-Et-2Btg-2Cg \\
\hline 25 & A & 40 & LS & $\mathrm{L}$ & 1.07 & 20 & - & - & 7.8 & Ap-Et-2Bt-2Ck-2Cg \\
\hline 26 & A & 50 & LS & $\mathrm{L}$ & 0.72 & 35 & - & - & 7.1 & Ap-Etg-2Btg-2Ckg \\
\hline 27 & A & 75 & LS & $\mathrm{L}$ & 0.54 & 35 & - & - & 6.9 & Ap-Et-2Btg-2Ckg \\
\hline 28 & A & 75 & LS & $\mathrm{L}$ & 0.77 & 30 & - & - & 6.7 & Ap-Etg-2Btg-2Cg \\
\hline 29 & $\mathrm{~F}$ & 22 & LS & $\mathrm{L}$ & 1.43 & 15 & - & - & 4.9 & Ap-Et-2Bt-2Ck \\
\hline
\end{tabular}

S - sands, LS - loamy sands, SL - sandy loams, L -loam, SCL - sandy clay loam; A - arable, F - forest 
$\mathrm{CaCO}_{3}$ content - volumetric Scheibler method; particle-size distribution - by sieve and sedimentary aerometric method; $\mathrm{pH}$ of soil-to-solution ratio of $1: 2.5$ using $1 \mathrm{M} \mathrm{KCl}$ and distilled $\mathrm{H}_{2} \mathrm{O}$ as the suspension medium. Color has been described according to Munsell Soil Color Charts (2000).
The systematic position and symbols/names of diagnostic horizons were given after the sixth edition of the Polish Soil Classification (PSC, 2019) and WRB (IUSS Working Group WRB, 2015). English-language names of soil units (PSC, 2019) were given as proposed by Kabała et al. (2019).

Table 2

Systematic position of studied soils

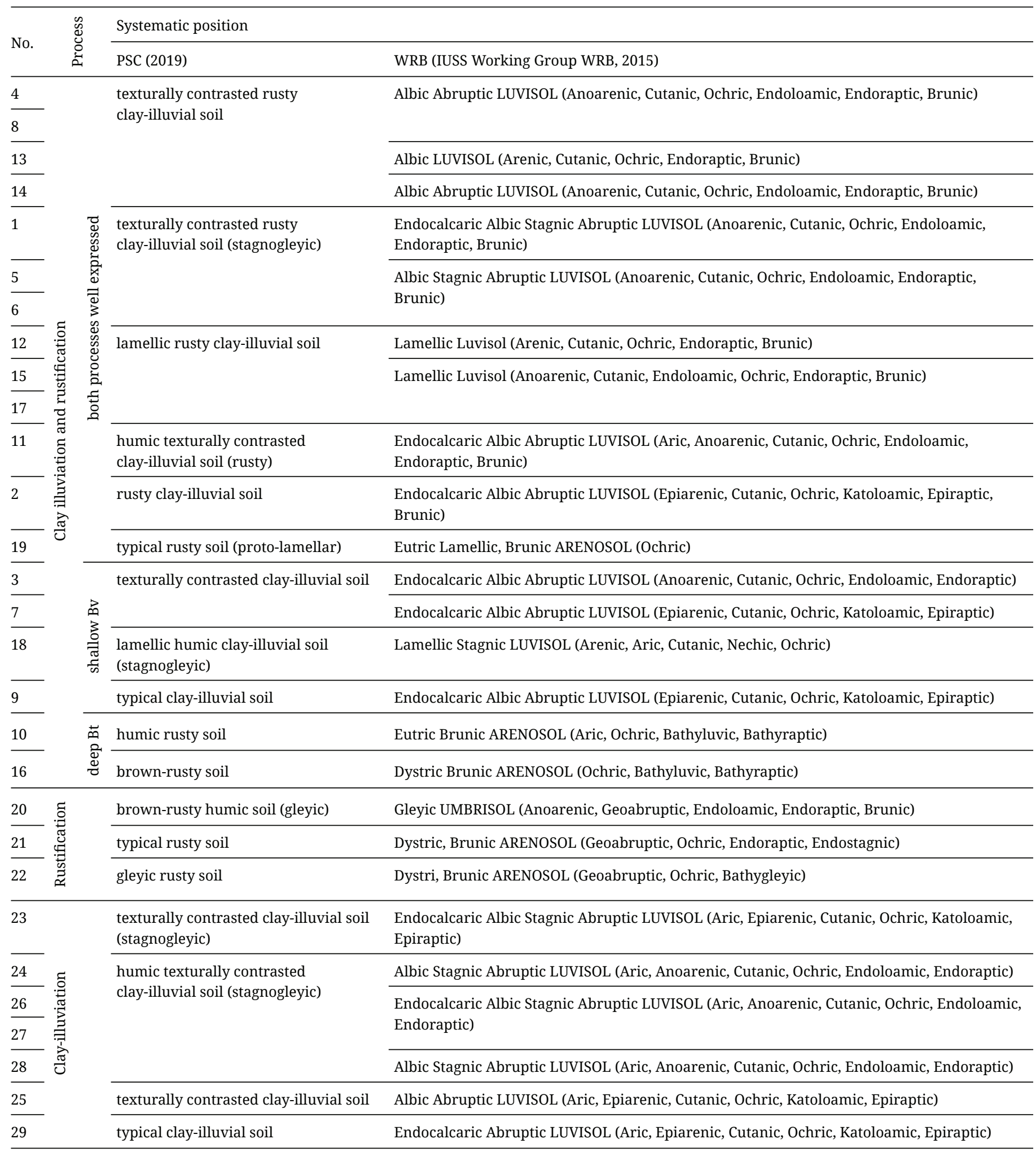




\section{Results}

Out of all analyzed profiles, as many as 19 (66\%) had distinct features of both processes - rustification and clay illuviation. In general, they are forest soils and have morphology: O-A-Bv-Et$2 \mathrm{Bt}-2 \mathrm{C}(\mathrm{k})$. Despite the fact that many of these soils occur in hilly areas - the soil cover, due to the protective role of the forest, does not show significant erosive transformations (Świtoniak 2014). The horizons Bv with sesquioxides accumulation occurred in these soils directly below the A horizons and had an average thickness of $31 \mathrm{~cm}$. Illuvial cutans were clearly visible in the stage of field works in theses soils, but illuviation was also confirmed by micromorphological investigation described in previous papers (Świtoniak 2014, Świtoniak et al. 2016). The clay-illuvial forms generally started below lithic discontinuity and formed continuous zone (13 profiles) or lamellaes (6 profiles). In 18 soils, the thickness of the zone with clay illuviation (or sum of lamellae's thickness) was sufficient to distinguish the argik (WRB - argic) horizon. Only in one profile (number 19) the "expression" of illuviation was too weak - total thickness of lamellae was not enough for distinguish argik (WRB - argic) horizon. The overlapping of the clay illuviation process on the lithological heterogeneity resulted in a significant contrast in the texture of the most of described cases.

Only in three cases clay illuviation forms were not observed. The rustification process dominated in sandy covers of these soils, accompanied by gleyization in lower, loamy part of profiles - O-A-Bv-2Cgg.

The remaining soils (7 profiles) had well-developed argik (argic-WRB) horizons (Ap-Etg-2Btg-2Cg(k)), but there was no accumulation of sesquioxides under the humus horizons. In most cases, some stagnation of rainwater was noted here, associated with a lower permeability of the glacial tills laying below lithic discontinuities. Moreover, all of these soils were under agricultural cultivation and were exposed to human-induced erosion.

\section{Discussion}

In terms of lithology all the studied soils met the conditions enabling the development of both processes - clay movement and rustification. The top of the profiles was sandy and coarsetextured and met the criterion of distinguishing siderik but at the same time contained sufficient clay fraction for possible development of lessive process. Out of 29 tested profiles, as many as 19 (66\%) showed the presence of features resulting from the both examined processes. Thus, the most common sequence of genetic horizons in the soils tested was: A-Bv-Et-2Bt-2C(k). Lack of the Bv horizons were noticed only in arable soils. The explanation for this state may be the destruction of these horizons as a result of human activity (plowing up to $30 \mathrm{~cm}$ ) and partial, erosive shallowing of the soil profiles (Kobierski, 2013; Świtoniak, 2014). Taking into account that the average depth of the lower boundary of Bv horizons in the examined forest soils is only 48 $\mathrm{cm}$, it can be assumed that in case of plowing up to $30 \mathrm{~cm}$ deep, only $18 \mathrm{~cm}$ of soil loss is enough to make these horizons completely disappear. The second reason for the lack of accumulation of sesquioxides may be periodic increased moisture over poorly permeable 2Bt horizons (visible in profiles as stagnic properties in Etg) - which increases the solubility and mobility of iron and aluminum compounds (Kowalkowski and Nowak, 1968; Jonczak 2013; Colombo et al., 2014) and enables more intensive leaching into deeper parts of profile. Taking into account that most of the clay-illuvial soils described in Poland belong to arable soils (exposed to erosion) or with finer texture in upper part of solum (e.g. Cieśla et al. 1978; Dąbkowska-Naskręt and Jaworska 1997; Stępniewski et al. 2000; Marcinek and Komisarek 2004; Paluszek, 2010; Podlasiński 2013; Loba et al. 2021) it is understandable why the A-E-B-C (without Bv) is described as a typical sequence for these soils. Only in three cases clay illuviation was not noted. In these soils, however, there was a strong gleyization in the lower part of the profile - which may have been the reason for the lack of illuvial features. The upper part of these soils was transformed by a rustification. The wide-spread coexistence of the features of clay illuviation and rustification in investigated forest pedons indicates that these processes are complementary under appropriate lithological conditions. The conducted research does not make it possible to determine whether they acted simultaneously in the same period or at different stages of soil formation. Taking into account the research of other authors the climatic conditions indicate that the lessivage process is, with certain periods of intensification - e.g. in the Atlantic, active since the beginning of the Holocene (e. g. Kühn, 2003; Budek, 2010). This is also confirmed by the studies of the illuvial bands in sandy soils - in some cases their age is determined at no more than 4800-4700 years (Prusinkiewicz et al., 1994).

In the case of rustification, some authors attributed this process to a periglacial or early Holocene genesis (Kowalkowski et al., 1981). Most recent studies of the origin of rusty soils, confirm that this process affected the sandy soils of Poland also in the later Holocene periods (Bednarek, 1991) and can be still active (Jankowski, 2014b; Papiernik et al., 2018). This would indicate that both described processes are taking place simultaneously - in the upper part of solum (Bv), the intensity of weathering and sesquioxides accumulation is higher than the rate of their leaching with the clay fraction into the deeper parts of profile (2Bt).

The polygenesis of the soils described is reflected in the names of taxons. According to the Polish Soils Classification (2019), all soils with a Bv thickness of more than $15 \mathrm{~cm}$ and an argik starting above $100 \mathrm{~cm}$ depth are classified as subtype rusty clay-illuvial soils. Due to lithological heterogeneity, they also generally met the criterion required for the texturally contrasted clay-illuvial subtype (texturally contrasted, rusty clay-illuvial soils). Pedons with Bt in form of lamellas could in turn be classified as lamellic rusty clay-illuvial soil. When the features of clayilluviation began deeper (more than $100 \mathrm{~cm}$ - profiles 10 and 16), the soils were classified as rusty soils only. The introduction of these subtypes to PSC 6 (2019) allows a precise reflection of their properties in the name of the soil subtype.

When the thickness of the Bv level was less than $15 \mathrm{~cm}$ - rusty subtype can not be used. According to WRB (IUSS Working Group WRB, 2015) pedons with A-Bv-Et-2Bt-2C(k) were classified in WRB as Abruptic Luvisols. Brunic qualifier (cor- 


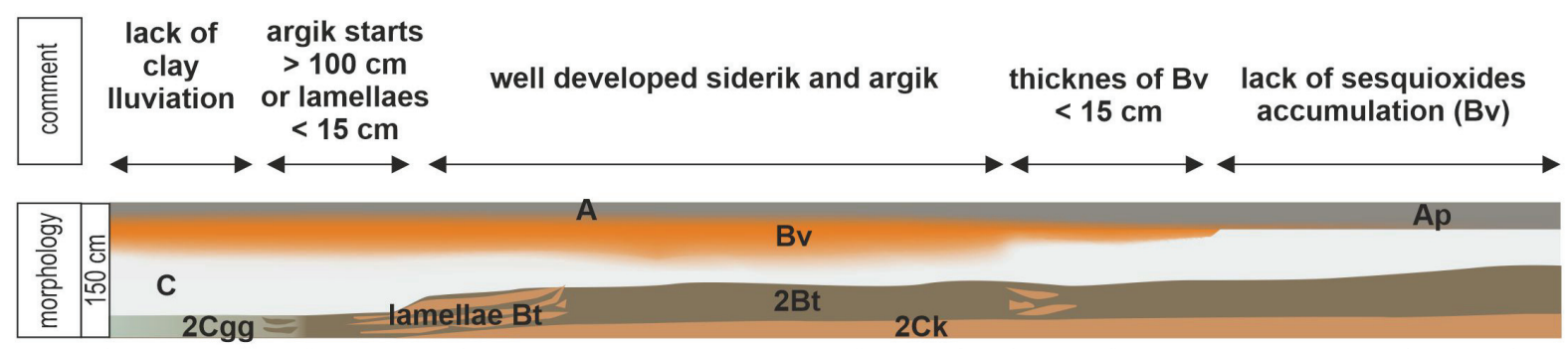

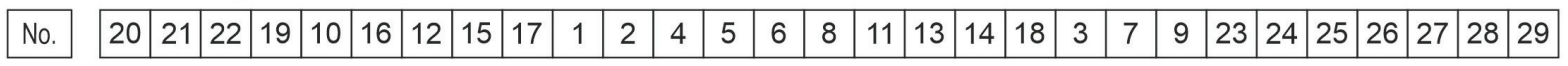

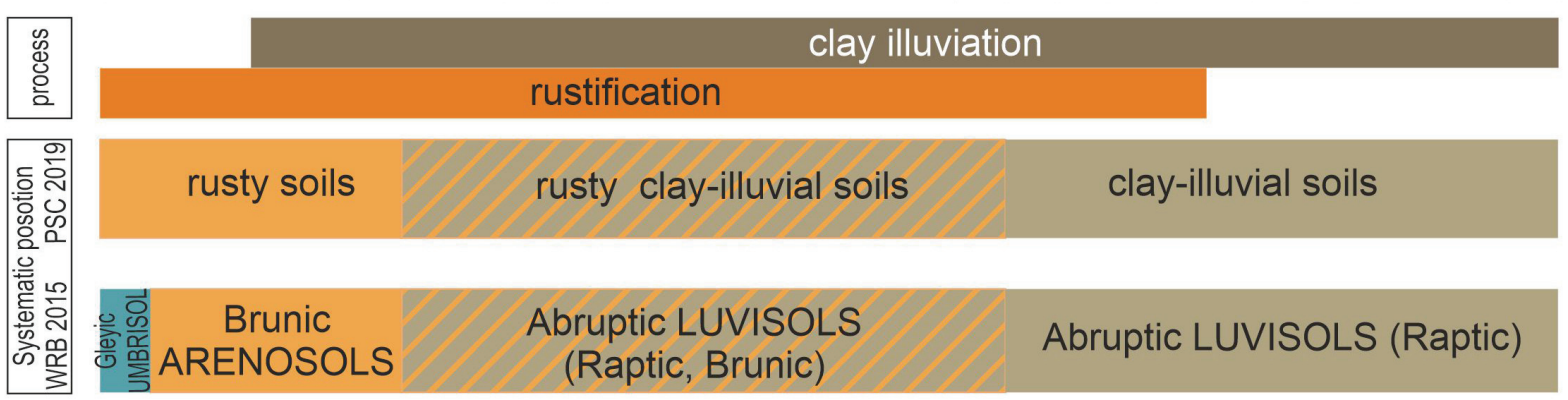

Fig. 2. Differentiation of properties and systematic position of the studied soils

responding to Siderik horizon in PSC 6) is not on the list of main or even supplementary qualifiers of this reference group. Despite its significant diagnostic importance, it can be added only at the end of the soil name. As well as the possibility of expressing the presence of cambic horizons (qualifier Neocambic) in Luvisols and Retisols - the Neobrunic qualifier should be added. Moreover, as in the case of PSC - Brunic cannot be applied with a Bv thickness of less than $15 \mathrm{~cm}$. In the case of argik with upper boundary deeper than $100 \mathrm{~cm}$, the soils passed to the Arenosols.

\section{Conclusions}

The conducted research allows for the redefinition of the "typical" set of soil-forming processes in textural contrasted lithologically heterogeneous sediments (sands on glacial tills) of young morainic areas. It should be noted that the process of clay translocation and the formation of lessive soils is often accompanied by the accumulation of sesquioxides in the upper part of the eluvial zone. Both processes could therefore be seen as complementary and characteristic of the humid subboreal climatic zone. Paleopedological and environmental studies by other authors indicate the possibility of simultaneous activity of both processes during the soil evolution. The results allow for the formulation of the following detailed conclusions:

- The coexistence of the clay-illuvation and rustification is not unique feature of texturally contrasted soils. The sequence A-Bv-Et-2Bt-2C(k) should be understood as an expression of the regular and common polygenesis of soils developed from sands covering glacial tills;

- Lack of Bv horizon in texturally contrasted clay-illuvial soils is often the result of 1) deepening the humus horizon during plowing, 2) erosive soil shallowing (truncation), 3) stagnation of water on $2 \mathrm{Bt}$ horizons
- The wide range of subtypes in clay-illuvial soils in PSC (2019) enables precise manifestation of the features of both processes. The studied soils belonged mainly to texturally contrasted or lamellic rusty clay-illuvial soils. The subtype expressing rustification in clay-illuviated soils was missing in earlier versions of the PSC.

- For the correct classification of the discussed soils, an additional qualifier - Neobrunic should be introduced in the WRB. It would be the equivalent of the Neocmbic qualifier already used in soils with argik horizons (Luvisols, Retisols) having finer texture and cambic horizon in the upper part of the soil profile.

\section{References}

Bednarek, R., 1991, Wiek, geneza i stanowisko systematyczne gleb rdzawych w świetle badań paleopedologicznych w okolicach Osia. Uniwersytet Mikołaja Kopernika, Toruń, 1-102. (in Polish with English summary)

Bednarek, R., Prusinkiewicz, Z., 1997. Geografia gleb. PWN, Warszawa. pp. 287. (in Polish)

Budek, A., 2010. Genesis and age of the humic horizons in the floodplain at the carpathian foreland. Geographical Studies Nr 222. 116 pp. (in Polish with English summary)

Cieśla, W., Wojtasik, M., Miraszewski, R., Rogalski, D., 1978. Gleby Wysoczyzny Chełmińskiej wytworzone z utworów pyłowych. Roczniki Gleboznawcze - Soil Science Annual 29(1), 127-140. (in Polish with English summary)

Colombo, C., Palumbo, G., He, JZ, Pinton, R., Cesco, S., 2014. Review on iron availability in soil: interaction of Fe minerals, plants, and microbes. Journal of Soils and Sediments 14, 538-548. https://doi.org/10.1007/ s11368-013-0814-z

Dąbkowska-Naskręt, H., Jaworska, H., 1997. Gleby płowe wytworzone z utworów pyłowych Pojezierza Chełmińsko-Dobrzyńskiego i Wysoczyzny Kaliskiej. Część I. Morfologia i właściwości fizykochemiczne. Roczniki Gleboznawcze - Soil Science Annual 48(1/2), 59-69. (in Polish with English summary) 
Duchaufour, P., 1982, Brunified soils. In: Pedology. Springer, Dordrecht. https://doi.org/10.1007/978-94-011-6003-2_10

Intergovernmental Panel on Climate Change (IPCC), 2006. IPCC Guidelines for National Greenhouse Gas Inventories. Volume 4. Egglestone, H.S., L. Buendia, K. Miwa, T. Ngara and K. Tanabe (Eds). Intergovernmental Panel on Climate Change (IPCC), IPCC/IGES, Hayama, Japan.

IUSS Working Group WRB, 2015. World Reference Base for soil resources 2014. International soil classification system for naming soils and creating legends for soil maps. Update 2015. World Soil Resources Report, 106. FAO, Rome

Jankowski, M., Kruczkowska, B., Bednarek, R., 2011. Topographical inversion of sandy soils due to local conditions in Northern Poland. Geomorphology 135(3-4), 277-283. DOI:10.1016/j.geomorph.2011.02.005

Jankowski, M., 2014a. The evidence of lateral podzolization in sandy soils of Northern Poland. Catena 112, 139-147. https://doi.org/10.1016/ j.catena.2013.03.013

Jankowski, M., 2014b, Bielicowanie jako wtórny proces w glebach rdzawych Brodnickiego Parku Krajobrazowego, [in:] M. Świtoniak, M. Jankowski, R. Bednarek (red.), Antropogeniczne przekształcenia pokrywy glebowej Brodnickiego Parku Krajobrazowego, Wydawnictwo Naukowe UMK, Toruń, 9-24.

Jonczak, J. 2013, Soil organic matter properties in Stagnic Luvisols under different land use types. Acta Agrophysica 20(4), 565-576.

Kabała, C., Charzyński, P., Chodorowski, J., Drewnik, M., Glina, B., Greinert, A., Hulisz, P., Jankowski, M., Jonczak, J., Łabaz, B., Łachacz, A., Marzec, M., Mendyk, Ł., Musiał, P., Musielok, Ł., Smreczak, B., Sowiński, P., Świtoniak, M., Uzarowicz, Ł., Waroszewski, J., 2019. Polish Soil Classification, $6^{\text {th }}$ edition - principles, classification scheme and correlations. Soil Science Annual 70(2), 71-97. https://doi.org/10.2478/ssa2019-0009

Kacprzak, A., Derkowski, A., 2007. Cambisols developed from cover-beds in the Pieniny Mts. (southern Poland) and their mineral composition. Catena 71(2), 292-297. https://doi.org/10.1016/j.catena.2007.01.004

Kobierski, M., 2013. Morphology, properties and mineralogical composition of eroded Luvisols in selected morainic areas of the Kujavian and Pomeranian Province. University of Technology and Life Sciences. Bydgoszcz.

Kondracki, J., 2009. Geografia regionalna Polski. Wydawnictwo Naukowe PWN, Warszawa.

Konecka-Betley, K. 1968. Zagadnienie żelaza w procesie glebotwórczym. Roczniki Gleboznawcze - Soil Science Annual 19(1), 51-97. (in Polish with English summary)

Konecka-Betley, K., Janowska, E., 1996. Wiek i pochodzenie osadów a niektóre procesy glebotwórcze. Roczniki Gleboznawcze - Soil Science Annual 47 (suppl.), 113-123. (in Polish with English summary)

Kottek, M., Grieser, J., Beck, C., Rudolf, B., Rubel, F. 2006. World Map of Köppen-Geiger Climate Classification updated. Meteorologische Zeitschrift 15, 259-263.

Kowalkowski, A., Nowak, G., 1968, Gleby bielicowe wzgórz ostrzeszowskich wytworzone z piasków akumulacji peryglacjalnej. Roczniki Gleboznawcze - Soil Science Annual 19(2), 365-377. (in Polish with English summary)

Kowalkowski, A. Borzyszkowski, J., Porębska, G., 1981. Geoekologiczne podstawy rozpoznawcze klasyfikacji i kartografii gleb rdzawych. IBL. Warszawa-Sękocin.

Kowalska, J.B., Skiba, M., Maj-Szeliga, K.. Mazurek R., Zaleski, T., 2021. Does calcium carbonate influence clay mineral transformation in soils developed from slope deposits in Southern Poland? Journal of Soils and Sediments 21, 257-280. https://doi.org/10.1007/s11368-02002764-3

Kruczkowska, B., Błaszkiewicz, M., Jonczak, J., Uzarowicz, Ł., Moska, P., Brauer, A., Bonk, A., Słowiński, M., 2020. The Late Glacial pedogenesis interrupted by aeolian activity in Central Poland - records from the Lake Gościąż catchment, Catena 185, https://doi.org/10.1016/ j.catena.2019.104286
Kühn, P., 2003. Micromorphology and Late Glacial/Holocene genesis of Luvisols in Mecklenburg-Vorpommern (NE-Germany). Catena 54, 537-555.

Kühn, P., Billwitz, K., Bauriegel, A., Kühn, D., Eckelmann, W., 2006. Distribution and Genesis of Fahlerden (Albeluvisols) in Germany. Journal of Plant Nutrition and Soil Science 169, 420-433.

Loba, A., Waroszewski, J., Tikhomirov, D., Calitri, F., Christl, M., Sykuła. M., Egli, M., 2021. Tracing erosion rates in loess landscape of the Trzebnica Hills (Poland) over time using fallout and cosmogenic nuclides. Journal of Soils and Sediments 21, 2952-2968. https://doi. org/10.1007/s11368-021-02996-X

Marcinek, J., Komisarek, J., 2004. Antropogeniczne przekształcenia gleb Pojezierza Poznańskiego na skutek intensywnego użytkowania rolniczego. AR. Poznań. (in Polish with English summary)

Marks, L., 2012. Timing of the Late Vistulian (Weichselian) glacial phases in Poland. Quaternary Science Reviews 44, 81-88.

Munsell Soil Colour Charts, 2000. GreagMacbeth, New Windsor.

Niewiarowski, W., 1959. Glacial forms and types of deglaciations on the moraine plateau of Chełmno (Bydgoszcz district). Studia Soc. Sci. Torun. Section C. 1. 4. Torun. (In Polish with English summary)

Niewiarowski, W., 1986. Morphogenesis of the Brodnica outwash on the background of ther glacial landforms of Brodnica Lake District. AUNC Geogr. 19(60), 3-30. (in Polish with English summary)

Niewiarowski, W., Wysota, W., 1986. Moraine plateau levels of the Brodnica Moraine Plateau and their genesis. Acta Universitatis Nicolai Copernici Geografia 19(60), 39-46. (in Polish with English summary)

Paluszek, J., 2010. The changes of soil cover as a result of erosion. Prace i Studia Geograficzne 45, 279-294. (in Polish with English summary)

Papiernik, P., Forysiak, J., Jankowski, M. 2018, Kształtowanie się powierzchni stanowiska w świetle procesów naturalnych oraz oddziaływania osadnictwa pradziejowego i czasów historycznych, [w:] Papiernik P., Płaza D.K. (red.) Od epoki kamienia do współczesności: badania archeologiczne w Redczu Krukowym na Kujawach. T. 1, Fundacja Badań Archeologicznych im. prof. K. Jażdżewskiego: Muzeum Archeologiczne i Etnograficzne, Łódź, 59-67.

Podlasiński, M., 2013. Denudation of anthropogenic impact on the diversity of soil cover and its spa-tial structure in the agricultural landscape of moraine. West Pomeranian University of Technology. Szczecin. (in Polish with English summary)

Prusinkiewicz, Z., Bednarek, R., 1983, Współzależność rozwoju gleb i roślinności w późnym plejstocenie i holocenie w północnej części sandru Wdy z uwzględnieniem wyników analizy palinologicznej. Cz. I: Geneza gleb rdzawych w świetle badań paleopedologicznych. Sprawozdanie z badań naukowych. V Komitet Badań Czwartorzędu PAN: 90794.

Prusinkiewicz, Z., Bednarek, R., Kosko, A., Szmyt, M., 1994. Age, properties and genesis of illuvial bands in the light of paleopedological and archaeological investigations. Roczniki Gleboznawcze - Soil Science Annual 45(1/2), 5-19. (in Polish with English summary)

Polish Soil Classification (Systematyka Gleb Polski), 2019. Soil Science Society of Poland, Commission on Soil Genesis, Classification and Cartography. Wydawnictwo Uniwersytetu Przyrodniczego we Wrocławiu, Polskie Towarzystwo Gleboznawcze, Wrocław - Warszawa: 235 pp.

Schaetzl, R.J., Anderson, S., 2005. Soils: Genesis and Geomorphology. Cambridge University Press.

Sinkiewicz, M., 1998. The development of anthropogenic denudation in central part of northern Poland. Nicolaus Copernicus University, Toruń. (in Polish with English summary)

Solon, J., Borzyszkowski, J., Bidłasik, M., Richling, A., Badora, K., Balon, J., Brzezińska-Wójcik, T., Chabudziński, Ł., Dobrowolski, R., Grzegorczyk, I., Jodłowski, M., Kistowski, M., Kot, R., Krąż, P., Lechnio, J., Macias, A., Majchrowska, M., Malinowska, E., Migoń, P., Myga-Piątek, U., Nita, J., Papińska, E., Rodzik, J., Strzyż, M., Terpiłowski, S., Ziaja, W., 2018. Physico-geographical mesoregions of Poland: Verification and adjustment of boundaries on the basis of contemporary spatial data. Geographia Polonica 91(2), 143-170. https://doi.org/GPol.0115 
Stępniewski, W., Stępniewska Z., Przywara, G., Brzezińska, M., Włodarczyk, T., 2000. Characteristics of aeration properties of Orthic Luvisol from Poland under different land use. International Agrophysics 14, 431-438.

Sykuła, M., Jankowski, M., Mendyk, Ł., Dąbrowski, M., Jasińska, J., Michalak, J., Michalski, A., Pindral, S., Bednarek, R., 2019. Wczoraj i dziś Mapy gleb Polski 1300000 - próba adaptacji do Systematyki gleb Polski 2019 (SGP6). W 30. Kongres Polskiego Towarzystwa Gleboznawczego - Gleba źródłem życia, Bartmiński P., Dębicki R. (red.). Uniwersytet Marii Curie-Skłodowskiej w Lublinie, Lublin, 108-109.

Świtoniak, M., 2014. Use of soil profile truncation to estimate influence of accelerated erosion on soil cover transformation in young morainic landscapes, North-Eastern Poland. Catena 116, 173-184. https://doi. org/10.1016/j.catena.2013.12.015

Świtoniak, M., Mroczek, P., Bednarek, R., 2016. Luvisols or Cambisols? Micromorphological study of soil truncation in young morainic landscapes - Case study: Brodnica and Chełmno Lake Dis- tricts (North Poland). Catena 137, 583-595. https://doi.org/10.1016/ j.catena.2014.09.005

Waroszewski, J., Egli, M., Kabała, C., Kierczak J., Brandova, D., 2016. Mass fluxes and clay mineral formation in soils developed on slope deposits of the Kowarski Grzbiet (Karkonosze Mountains, Czech Republic/Poland). Geoderma 264B, 363-378. https://doi.org/10.1016/ j.geoderma.2015.08.044

Wójcik, G., Marciniak, K., 1987a. Thermal conditions in central part of the North Poland in the years 1951-1970. Acta Universitatis Nicolai Copernici Geografia 20, 29-50. (in Polish)

Wójcik, G., Marciniak, K., 1987b. Precipitations in central part of the North Poland in the years 1951-1970. Acta Universitatis Nicolai Copernici Geografia 20, 51-69. (in Polish)

Yost, J.L., Roden, E., Hartemink, A.E., 2019. Geochemical fingerprint and soil carbon of sandy alfisols. Soil Systems 3(3), 59. https://doi. org/10.3390/soilsystems3030059

\section{Rdzawienie jako proces towarzyszący iluwiacji iłu w glebach północnej Polski}

\section{Słowa kluczowe}

Gleby strefowe

Siderik

Gleby płowe

Gleby rdzawe

Lessiważ

\section{Streszczenie}

Proces lessiważu i rdzawienia należą do dwóch najbardziej powszechnych procesów glebotwórczych na terenie naszego kraju. Poziomy iluwialnego nagromadzenia frakcji iłowej obserwowane są w ok. 50\% gleb Polski podczas gdy gleby rdzawe stanowią około $14 \%$ - czyli prawie połowę wszystkich gleb piaszczystych. Ze względu na odmienne uwarunkowania obu procesów - głównie o charakterze litologicznym - są one generalne postrzegane jako zjawiska występujące rozłącznie i prowadzące do powstania dwóch różnych typów gleb - gleb płowych i gleb rdzawych. W niektórych profilach glebowych - szczególnie wytworzonych z piasków naglinowych, obserwowane są jednak efekty obu tych procesów glebotwórczych. Celem prezentacji jest charakterystyka gleb, w których jedocześnie można zaobserwować cechy związane z iluwialnym nagromadzeniem frakcji ilastej (lessiważ) oraz nagromadzenia półtoratlenków żelaza w formie otoczek żelazistych wytworzonych in-situ w materiale piaszczystym (proces rdzawienia). W celu sprawdzenia jak często procesy te zachodzą symultanicznie przeanalizowano 29 profili glebowych o uziarnieniu umożliwiającym jednoczesny przebieg obu procesów w obszarach młodoglacjalnych Polski północnej. Aż w 66\% przypadków stwierdzono obecność cech związanych z obydwoma procesami. Brak procesu rdzawienia odnotowano jedynie w glebach ornych - często spłyconych erozyjnie lub mających wyraźne oglejenie opadowo-wodne w poziomie eluwialnym. Większość z badanych gleb zaklasyfikowana została jako gleby płowe dwudzielne rdzawe (WRB - Abruptic Luvisols (Brunic)) lub gleby płowe lamellowe rdzawe (WRB - Lamellic Luvisols (Brunic)). Oba procesy w glebach wytworzonych z piasków naglinowych są więc względem siebie komplementarne, a profile o budowie ABv-Et-2Bt-2Ck powinny być postrzegane jako w pełni ukształtowane i niezaburzone działalnością człowieka. 